\title{
Heparin stability: effects of diluent, heparin activity, container, and $\mathrm{pH}$
}

\author{
KENNETH T GOODALL, CHEE-CHOONG CHOOI, AND \\ ALEXANDER S GALLUS
}

From the Department of Haematology, Flinders Medical Centre, Bedford Park, South Australia 5042, Australia

SUMMARY The effects have been studied of diluent, heparin activity after dilution, container, and $\mathrm{pH}$ on the stability of heparin solutions stored under conditions resembling those present during heparin infusion by intravenous drip or syringe pump. Heparin activity was measured by activated partial thromboplastin time and thrombin clotting time (and, in one set of studies, also by factor $\mathrm{Xa}$ inhibitor assay and protamine sulphate neutralisation).

Heparin activity was stable for 6 hours regardless of storage conditions. After 24 hours heparin activity was stable when the drug was diluted in $0.9 \%$ saline and stored in plastic, but a small loss of activity was observed in several studies after dilution in $5 \%$ dextrose or storage in glass. A more extensive comparison confirmed a 3-5\% loss in heparin activity over 24 hours after dilution in $5 \%$ dextrose. Changing the $\mathrm{pH}$ to 3.5 or 10.0 had little effect on storage stability.

We conclude that heparin activity in vitro remains stable during short infusions but recommend dilution in $0.9 \%$ saline and a plastic container when a heparin solution is infused over 24 hours.

Heparin is now commonly given by continuous intravenous infusion rather than by intermittent injection. For this mode of administration heparin is diluted in one of several intravenous infusion fluids and may then remain at room temperature in the infusion bag, bottle, or syringe for 8-24 hours. It is, therefore, important to know if its anticoagulant activity remains stable in vitro for this time.

This question has been repeatedly investigated with varying results (Table). Thus, it has been reported that heparin activity is constant for 24 hours regardless of the diluting fluid or its $\mathrm{pH}$ over a wide range, ${ }^{1-4}$ or that heparin activity is reduced by $40-50 \%$ within 1 hour of dilution except in $0.9 \%$ sodium chloride, ${ }^{5}$ or that heparin activity is reduced by $50-60 \%$ after $4-6$ hours in all diluents but then increases again with further storage. ${ }^{6}$

Because of these contradictory and sometimes confusing reports about heparin stability in vitro we decided to re-investigate the question.

Further, because there is disagreement about the most appropriate test of heparin effect, we decided to measure heparin stability in vitro using four tests: the

Received for publication 17 December 1979 activated partial thromboplastin time (APTT), the thrombin clotting time (TCT), factor Xa inhibitory activity (Xa time), and protamine sulphate neutralisation.

\section{Methods}

STUDY DESIGN

Sodium heparin was added to $500 \mathrm{ml} 0.9 \%$ saline or $5 \%$ dextrose, supplied commercially for intravenous use in plastic bags or glass bottles, to give a heparin activity of 10,20 , or $40 \mathrm{IU} / \mathrm{ml}$, and to $50 \mathrm{ml} 0.9 \%$ saline or $5 \%$ dextrose drawn into a plastic syringe to give a heparin activity of 400 or $1000 \mathrm{IU} / \mathrm{ml}$. These conditions were chosen to mimic those obtaining during heparin infusion by intravenous drip or syringe pump. Heparin activity was assayed immediately and after 3,6 , and 24 hours of room temperature storage. In addition, heparin stability was measured during storage at varying $\mathrm{pH}$.

HEPARIN AND INTRAVENOUS FLUIDS

Mucous heparin BP (1000 or $5000 \mathrm{IU} / \mathrm{ml})$ was obtained from Allen and Hanbury's Division of Glaxo Australia Pty Ltd (Boronia, Victoria). Intra- 
Previously reported changes in heparin activity after dilution and storage

\begin{tabular}{|c|c|c|c|c|c|c|}
\hline Authors & $\begin{array}{l}\text { Heparin } \\
\text { activity } \\
(U / m l)\end{array}$ & $\begin{array}{l}\text { Storage } \\
\text { (hours) }\end{array}$ & Diluting fluid & $p H$ & Assay & Conclusions \\
\hline $\begin{array}{l}\text { Stock and Warner } \\
(1971)^{1}\end{array}$ & $\begin{array}{r}964 \\
200 \\
40\end{array}$ & 24 & $5 \%$ Dextrose & $\begin{array}{l}7 \cdot 0 \\
6 \cdot 8 \\
6 \cdot 6\end{array}$ & Not described & No loss of activity \\
\hline $\begin{array}{l}\text { Hodby et al. } \\
(1972)^{2}\end{array}$ & 32 & 24 & $\begin{array}{l}0.9 \% \text { Sodium chloride } \\
5 \% \text { Dextrose } \\
\text { Dextrose saline } \\
0.9 \% \text { Sodium chloride } \\
0.9 \% \text { Sodium chloride }\end{array}$ & $\begin{array}{l}6 \cdot 9 \\
7 \cdot 2 \\
6 \cdot 9 \\
3 \cdot 2 \\
6 \cdot 9\end{array}$ & APTT & No loss of activity \\
\hline $\begin{array}{l}\text { Mitchell et al. } \\
(1976)^{3}\end{array}$ & 20,40 & 48 & $\begin{array}{l}\text { Normal saline } \\
5 \% \text { Dextrose }\end{array}$ & $\begin{array}{l}5 \cdot 2-7 \cdot 0 \\
5 \cdot 5-6 \cdot 8\end{array}$ & TCT & No loss of activity \\
\hline $\begin{array}{l}\text { Joy et al. } \\
(1979)^{4}\end{array}$ & 20 & 24 & $\begin{array}{l}5 \% \text { Dextrose } \\
0.45 \% \text { Saline } \\
5 \% \text { Dextrose }\end{array}$ & $2 \cdot 0-9 \cdot 0$ & TCT & No loss of activity \\
\hline $\begin{array}{l}\text { Jacobs et ol. } \\
(1973)^{5}\end{array}$ & 20 & 24 & $\begin{array}{l}\text { Normal saline } \\
5 \% \text { Dextrose } \\
\text { Saline/Dextrose } \\
\text { Ringer lactate } \\
\text { Saline lactate }\end{array}$ & $\begin{array}{l}6 \cdot 8 \\
3 \cdot 9 \\
3 \cdot 9 \\
6 \cdot 3 \\
6 \cdot 3\end{array}$ & Modified TCT & $\begin{array}{l}\text { No loss of activity } \\
\simeq 50 \% \text { loss of activity } \\
\simeq 40 \% \text { loss of activity } \\
\simeq 50 \% \text { loss of activity } \\
\simeq 50 \% \text { loss of activity }\end{array}$ \\
\hline $\begin{array}{l}\text { Okuno and Nelson } \\
\text { (1975) }\end{array}$ & 10 & 24 & $\begin{array}{l}\text { Normal saline } \\
5 \% \text { Dextrose } \\
10 \% \text { Dextrose } \\
2 \frac{1}{2} \% \text { Dextrose } \\
\text { Hartmann's solution }\end{array}$ & $5 \cdot 5-6 \cdot 9$ & $\begin{array}{l}\text { Xa inhibitor } \\
\text { TCT }\end{array}$ & $\begin{array}{l}\text { Marked loss of activity } \\
\text { within } 4 \text { hours, then } \\
\text { complete recovery by } \mathrm{Xa} \\
\text { inhibitor assay but not by } \\
\text { TCT }\end{array}$ \\
\hline
\end{tabular}

venous fluids were obtained in plastic bags from Travenol Laboratories Pty Ltd (Sydney) and in glass bottles from Abbott Laboratories Pty Ltd (Sydney). Plastic syringes were supplied by Terumo Australia Pty Ltd (Melbourne).

In some experiments the $\mathrm{pH}$ of $0.9 \%$ saline and $5 \%$ dextrose was adjusted to 3.5 or 10.0 with $0.1 \mathrm{~N}$ $\mathrm{HCl}$ or $0.1 \mathrm{~N} \mathrm{NaOH}$ before the addition of heparin.

\section{HEPARIN ACTIVITY MEASUREMENTS}

Heparin solutions were subsampled into pooled normal platelet poor plasma for the measurement of heparin activity after each storage interval. After a preliminary dilution, 10 or $20 \mu$ l of heparin solution were added to $1.0 \mathrm{ml}$ plasma to yield a calculated final plasma activity of $0.2 \mathrm{IU} / \mathrm{ml}$ (assuming no change in activity with storage). All tests were done in duplicate at least five times by two workers using coded samples. Samples were stored on melting ice until tests had been done.

To prepare the normal plasma, blood was collected from volunteer blood donors into $3.8 \%$ tri-sodium citrate ( 9 parts blood: 1 volume citrate) and centrifuged at $2000 \mathrm{~g}$ for 30 minutes at $4^{\circ} \mathrm{C}$. Pooled normal plasma from 20 donors was then stored in small aliquots at $-70^{\circ} \mathrm{C}$. The same batch of pooled normal plasma was used for each set of studies.

Heparin activity was measured with the APTT and the TCT in all studies, and, in one series of experiments, heparin activity was also measured by a factor $\mathrm{Xa}$ inhibitor method (Xa time) ${ }^{7}$ and by protamine sulphate neutralisation. ${ }^{8}$ All tests were done using a clot-detecting device (Clotek, Hyland), except for the
Xa time, which was measured using a manual (hook) technique.

The observed clotting times for each test were converted to heparin activity (IU/ml) by the use of standard heparin sensitivity curves for each test (see below, and Figs 1-3).

Automated APTT reagent was obtained from General Diagnostics (Morris Plains, New Jersey) and used according to the manufacturer's instructions. The TCT was measured after diluting Topical

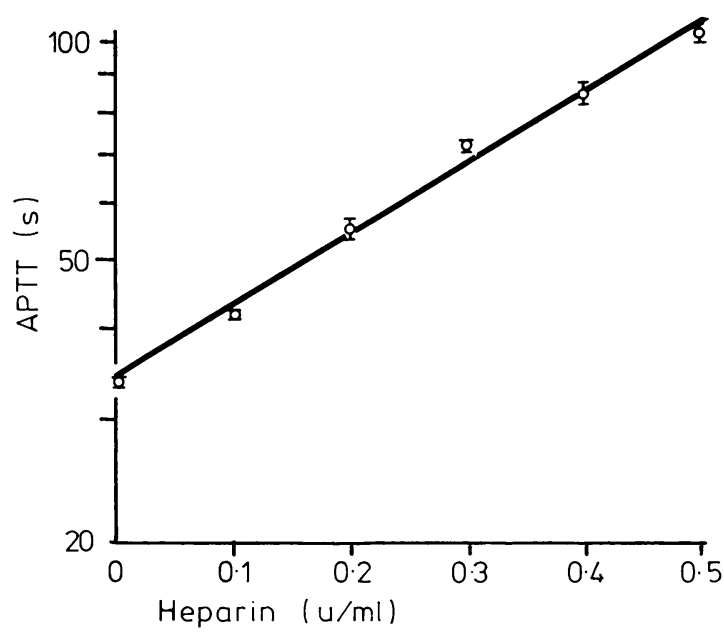

Fig. 1 Heparin sensitivity of APTT. The mean APTT \pm SEM is plotted for each heparin activity tested. The line of best fit was derived by least squares analysis. 


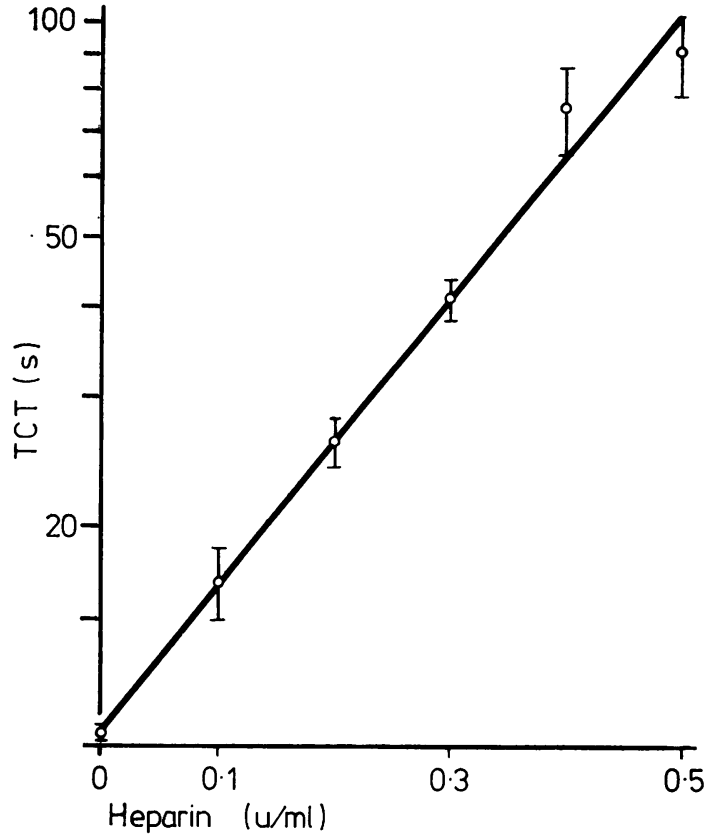

Fig. 2 Heparin sensitivity of TCT. The mean TCT \pm SEM is plotted for each activity tested.

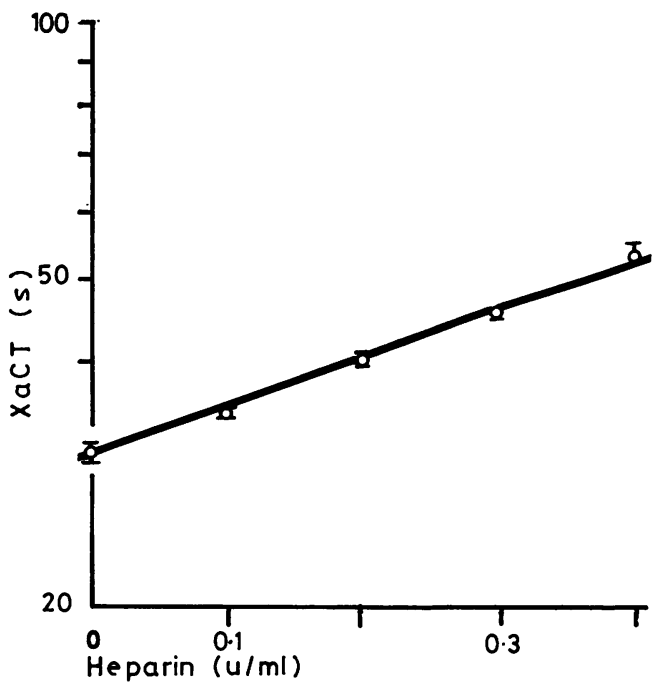

Fig. 3 Heparin sensitivity of factor Xa inhibitor assay $(X a C T)$. The mean XaCT $\pm S E M$ is plotted for each activity tested.
Thrombin (Parke Davis, Detroit, Michigan) to an activity of 5 units $/ \mathrm{ml}$ in $0.1 \mathrm{M}$ calcium chloride and adding $0.1 \mathrm{ml}$ of this reagent to $0.2 \mathrm{ml}$ platelet poor plasma.

The Xa time was measured using the Deci Unit range of method A of Yin et al. ${ }^{7}$ Reagents for this test were obtained from Sigma Chemicals Co (St Louis, Mo).

Protamine sulphate neutralisation was done as described by Refn and Vestergaard ${ }^{8}$ using dilutions of protamine sulphate $(10 \mathrm{mg} / \mathrm{ml})$ supplied by Boots Co Ltd (Nottingham, England).

HEPARIN SENSITIVITY CURVES AND

HEPARIN RECOVERY FROM PLASMA

The sensitivities of the APTT, TCT, and Xa CT to heparin are shown in Figures 1-3. These curves were derived by adding appropriate dilutions of the heparin batch used in the stability studies to pooled normal platelet poor plasma and measuring clotting times in duplicate on five separate occasions.

To check heparin recovery from the pooled normal plasma used in these studies, protamine sulphate was used to neutralise a crystalline porcine sodium mucous heparin (169 IU/mg) obtained by courtesy of Dr Peter Forsell, Allen and Hanbury's, Boronia, Victoria. $100 \mathrm{IU}$ of this heparin was neutralised by $1.045 \mathrm{mg}$ of protamine sulphate. When $0.2 \mathrm{IU} / \mathrm{ml}$ of this standard heparin was added to pooled normal plasma, $0.19 \mathrm{IU} / \mathrm{ml}$ could be measured by protamine sulphate neutralisation, indicating substantially complete recovery.

STATISTICAL METHODS

Lines of best fit for heparin activity-test response curves were derived by the method of least squares. Change of heparin activity with time was tested by paired $t$ test and analysis of variance. All results in text and figures are expressed as mean \pm standard error of mean (SEM).

\section{Results}

HEPARIN RECOVERY

At zero time, all heparin solutions showed the predicted heparin activity with all test systems used, so that subsequent results were expressed as a percent of the initial measured activity.

\section{PLASTIC CONTAINERS}

There was no significant loss of activity when heparin was diluted in $\mathbf{0 . 9} \%$ saline and stored for 24 hours in plastic containers (bag or syringe) (Figs 4, $5,7)$. This occurred regardless of the heparin dilution, the storage $\mathrm{pH}$, and whether heparin activity was measured by APTT, TCT, or (with the $10 \mathrm{IU} / \mathrm{ml}$ 


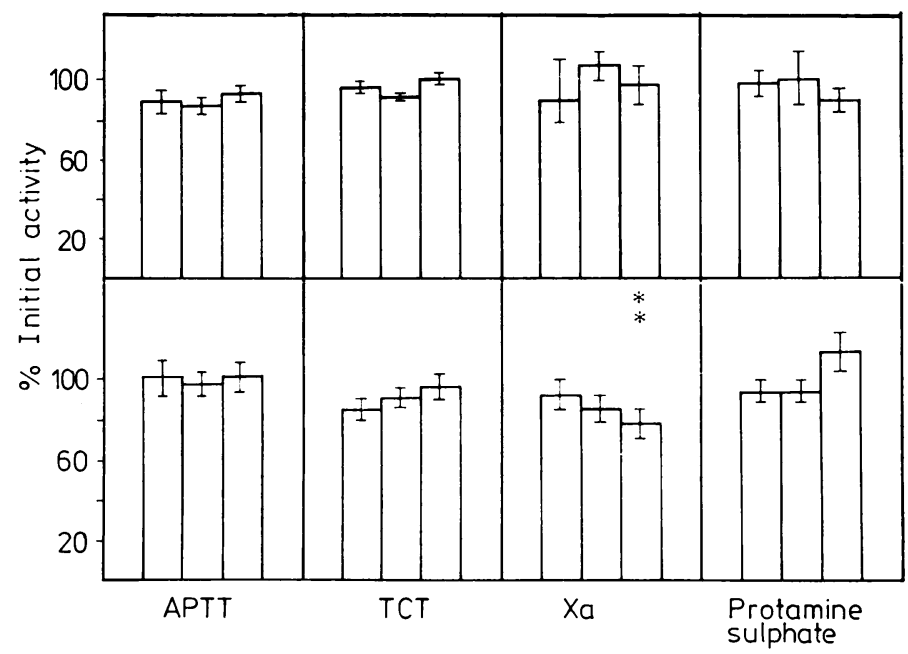

Fig. 4 Heparin stability tested by APTT, TCT, Xa time (Xa), and protamine sulphate neutralisation after heparin was diluted to $10 \mathrm{IU} / \mathrm{ml}$ and stored in commercial solutions of $0.9 \%$ saline (above) or $5 \%$ dextrose (below) sold for intravenous use in plastic bags. Bars represent percent of initial activity \pm SEM after 3, 6, and 24 hours' storage. ${ }^{* *} \mathrm{P}<0.01$ when activity after storage was compared with initial activity.

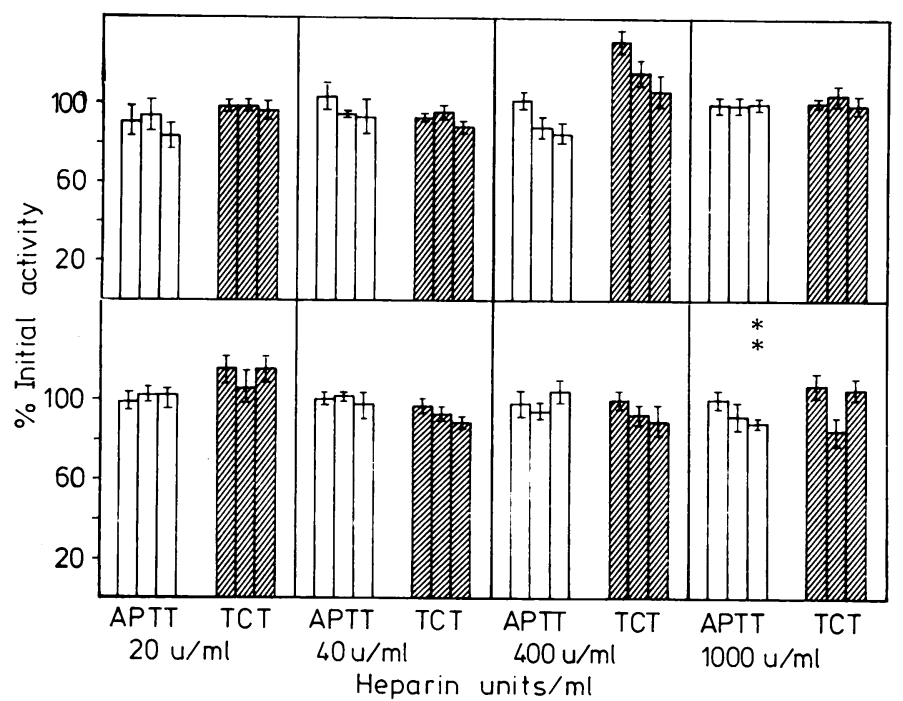

Fig. 5 Heparin stability tested by APTT (clear bars) and TCT (shaded bars) after dilution to $20 \mathrm{IU} / \mathrm{ml}, 40 \mathrm{IU} /$ $\mathrm{ml}, 400 \mathrm{IU} / \mathrm{ml}$, and $1000 \mathrm{IU} / \mathrm{ml}$ in $0.9 \%$ saline (above) or $5 \%$ dextrose (below), and storage for 3, 6, and 24 hours in plastic bags $(20 \mathrm{IU} / \mathrm{ml}$ and $40 \mathrm{IU} / \mathrm{ml})$ or plastic syringes. Bars represent percent of initial activity \pm SEM. ${ }^{*} \mathrm{P}<0.05$ ${ }^{* *} \mathrm{P}<0.01$ (compared with initial activity).

solution) by Xa time or protamine sulphate neutralisation. Similarly, there was at most a small loss of activity when heparin was diluted in $5 \%$ dextrose solution and kept in plastic containers. There was a statistically significant decrease in activity after 24 hours when the $10 \mathrm{IU} / \mathrm{ml}$ solution was tested by $\mathrm{Xa}$ time (Fig. 4), the $40 \mathrm{IU} / \mathrm{ml}$ solution was tested by TCT (Fig. 5), the $1000 \mathrm{IU} / \mathrm{ml}$ solution was tested by APTT (Fig. 5), and the pH 10, $20 \mathrm{IU} / \mathrm{ml}$ solution was tested by APTT (Fig. 7), but the apparent loss of activity was small: $9-11 \%$ in all cases except for a $23 \%$ loss of activity measured by Xa time.

\section{GLASS BOTTLES}

In several experiments a statistically significant $10-14 \%$ loss of activity was recorded after 24 hours' storage in glass bottles. This was seen when activity was measured by APTT (10 IU/ml, $0.9 \%$ saline) or TCT $(40 \mathrm{IU} / \mathrm{ml}, 0.9 \%$ saline; $20 \mathrm{IU} / \mathrm{ml}, 40 \mathrm{IU} / \mathrm{ml}, 5 \%$ dextrose) (Fig. 6).

\section{CONFIRMATORY STUDIES}

In a second series of studies, $10 \mathrm{IU} / \mathrm{ml}$ heparin was stored for 24 hours in $20500-\mathrm{ml}$ plastic bags of $0.9 \%$ saline and $20500-\mathrm{ml}$ bags of $5 \%$ dextrose, and 


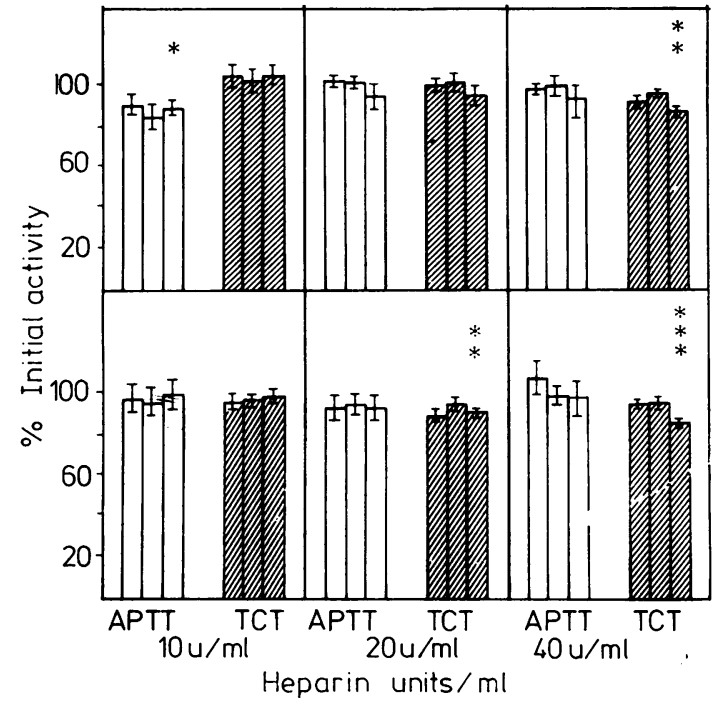

Fig. 6 Heparin stability tested by APTT (clear bars) and TCT (shaded bars) after dilution to $10 \mathrm{IU} / \mathrm{ml}, 20 \mathrm{IU} / \mathrm{ml}$, and $40 \mathrm{IU} / \mathrm{ml}$ in commercial solutions of $0.9 \%$ saline (above) or $5 \%$ dextrose (below) sold for intravenous use in glass bottles. Bars represent percent of initial activity $\pm S E M$ after 3, 6, and 24 hours' storage. ${ }^{*} \mathrm{P}<0.05{ }^{* *} \mathrm{P}<0.01{ }^{* * *} \mathrm{P}<0.001$ (compared with initial activity).

heparin activity was measured by APTT and TCT at zero time and after 24 hours.

There was no change of heparin activity in $0.9 \%$ saline (24-hour APTT $=99.9 \pm 0.6 \% ; 24$-hour TCT $=100.3 \pm 0.6 \%$ of initial activity), but a very small though statistically significant decrease of heparin activity in 5\% dextrose (24-hour APTT = $97 \cdot 3 \pm 0 \cdot 9 \%, 24$-hour TCT $=95 \cdot 1 \pm 1 \cdot 3 \%$ of initial activity; $\mathrm{P}<0.01$ for both observations).

\section{Discussion}

Our results suggest that there is no loss of heparin activity when heparin is diluted in $0.9 \%$ saline and stored in plastic for 24 hours at room temperature. Heparin also appears to be stable for 6 hours under other storage conditions, but a small loss was observed in some studies after 24 hours when the drug was diluted in $5 \%$ dextrose or stored in glass; this loss was no greater than $10-15 \%$ of initial activity. Further studies comparing heparin stability in $0.9 \%$ saline and $5 \%$ dextrose in plastic bags, using a larger sample of 20 , confirmed that heparin is stable for 24 hours in $0.9 \%$ saline, but showed a $3-5 \%$ loss of activity in $5 \%$ dextrose. Any loss of activity associated with storage at the $\mathrm{pH}$ extremes

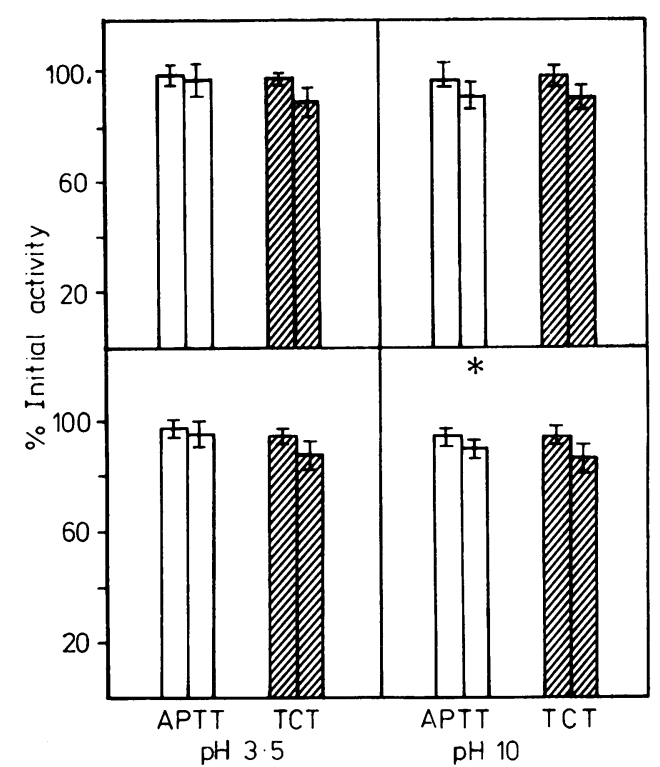

Fig. 7 Effect of pH 3.5 and $p H 10$ on heparin stability tested by APTT (clear bars) and TCT (shaded bars) 6 and 24 hours after dilution of heparin to $20 \mathrm{IU} / \mathrm{ml}$ in $0.9 \%$ saline (above) or $5 \%$ dextrose (below) sold for intravenous use in plastic bags. Bars represent percent of initial activity $\pm S E M^{*} \mathrm{P}<0.05$.

of 3.5 and 10.0 was also small.

These conclusions are similar to those of most previous reports ${ }^{1-4}$ and are consistent with the stable anticoagulant response to a 12-hour infusion of heparin diluted in $5 \%$ dextrose observed by Chessels et al. ${ }^{9}$

Our results do not confirm the marked loss of heparin activity reported after dilution in 5\% dextrose by Jacobs et al., 5 and after dilution in $5 \%$ dextrose or $0.9 \%$ saline by Okuno and Nelson ${ }^{6}$ (Table), and we are unable to explain these discrepancies. Our methods of measuring heparin activity differ from those used by Jacobs et al. ${ }^{5}$ but are similar to those of Okuno and Nelson. ${ }^{6}$

We conclude that heparin activity in vitro remains stable during a short infusion, but, because of the small loss in activity after 24 hours when heparin is diluted in $5 \%$ dextrose or stored in glass, we recommend dilution in $0.9 \%$ saline and storage in plastic containers when a heparin solution is to be infused over 24 hours.

We thank Miss J Tillett for able technical help, Dr Peter Forsell, of Allen and Hanbury's, for supplying crystalline heparin, and Mrs Jenny Riddle and Mrs Sheila Phillips for typing the manuscript. 


\section{References}

${ }^{1}$ Stock SL, Warner N. Heparin in acid solution. Br Med J 1971;3:307.

2 Hodby ED, Hirsh J, Adeniyi-Jones C. The influence of drugs upon the anticoagulant activity of heparin. Can Med Assoc J 1972;106:562-4.

${ }^{3}$ Mitchell JF, Barger RC, Cantwell L. Heparin stability in $5 \%$ dextrose and $0.9 \%$ sodium chloride solutions. Am J Hosp Pharm 1976;33:540-2.

4 Joy RT, Hyneck ML, Bernardi RR, Ho NFH. Effect of p H on the stability of heparin in 5\% dextrose solution. Am J Hosp Pharm 1979;36:618-21.

${ }^{5}$ Jacobs J, Kletter D, Superstine E, Hill KR, Lynn B, Webb RA. Intravenous infusions of heparin and penicillins.
$J$ Clin Pathol 1973;26:742-6.

- Okuno T, Nelson CA. Anticoagulant activity of heparin in intravenous fluids. J Clin Pathol 1975;28:494-7.

7 Yin ET, Wessler S, Butler JV. Plasma heparin: a unique, practical submicrogram-sensitive assay. J Lab Clin Med $1973 ; 81: 298-310$.

${ }^{8}$ Refn I, Vestergaard L. The titration of heparin with protamine. Scand J Clin Lab Invest 1954;6:284-7.

${ }^{9}$ Chessels JM, Braithwaite TA, Chamberlain DA. Dextrose and sorbitol as diluent for continuous intravenous heparin infusion. $\mathrm{Br} \mathrm{Med} J$ 1972;2:81-2.

Requests for reprints to: Dr AS Gallus, Department of Haematology, Flinders Medical Centre, Bedford Park, South Australia 5042.

\section{Reports and Bulletins prepared by the Association of Clinical Biochemists}

The following reports and bulletins are published by the Association of Clinical Biochemists. They may be obtained from The Publishing Department, British Medical Journal (ACB Technical Bulletins), BMA House, Tavistock Square, London WC1H 9JR. Overseas readers should remit bv British Postal or Money Order.

SCIENTIFIC REVIEWS (price $£ 1 \cdot 00 / \$ 2.00$ each)

1 The assessment of thyroid function March 1971 FV FLYNN and JR HOBBS

2 Renal function tests suitable for clinical practice January 1972 FL MITCHELL, N VEALL, and RWE WATTS

3 Biochemical tests for the assessment of fetoplacental function May 1975 CE WILDE and RE OAKEY

4 Test of exocrine pancreatic function March 1977 AH GOWENLOCK

5 Assay of cholinesterase in clinical chemistry March 1979 ELSIE SILK, J KING, and MARY WHITTAKER

TECHNICAL BULLETINS (price $£ 1 \cdot 00 / \$ 2.00$ each)

22 Bilirubin standards and the determination of bilirubin by manual and technicon AutoAnalyzer methods January 1971 BARBARA BILLING, RUTH HASLAM, and $\mathrm{N}$ WALD

23 Interchangeable cells for spectrophotometers and fluorimeters September 1971 ss BROWN and AH GOWENLOCK

24 Simple tests to detect poisons March 1972 BW MEADE et al.

25 Blood gas analysers May 1972 K DIXON

$26 \mathrm{Kits}$ for enzyme activity determination September 1972 SB ROSALKI and D TARLOW

27 Assessment of pumps suitable for incorporation into existing continuous flow analytical systems November 1972 A FLECK et al.

28 Routine clinical measurements of transferrin in human serum September 1973 K DIXON
29 Control materials for clinical biochemistry (5th edition) September 1973 JF STEVENS

30 Notes on the quality of performance of serum cholesterol assays September 1973 ss BROWN

31 Determination of uric acid in blood and in urine July 1974 RWE WATTS

32 A survey of amino acid analysers readily available in the United Kingdom September 1974 JE CARLYLE and P PURKISs

33 Definitions of some words and terms used in automated analysis November 1974 A FLECK, R ROBINSON, SS BROWN, and JR HOBBS

34 Measurement of albumin in the sera of patients January 1975 LINDA SLATER, PM CARTER, and JR HOBBS

35 Investigation of the validity of temperature correction factors for serum aspartate and alanine transaminases March 1975 SB ROSALKI et al.

36 Factors influencing the assay of creatinine November 1975 JGH COOK

37 A survey of enzyme reaction rate analysers readily available in the United Kingdom July 1977 RA SAUNDERS and RF BURNS

38 Transport of specimens for clinical chemistry analysis November 1977 P WILDING, JF ZILVA, and CE WILDE

39 A scheme for the evaluation of diagnostic kits May 1978 PH LLOYD

40 A practical guide to gamma-counting in radioimmunoassay January 1980 CE WILDE and D OTTEWELL

41 The use of biochemical tests (in the diagnosis of disorders of calcium metabolism July 1980 ANGELA FAIRNEY 